Nagaev Viktor, Doctor of Pedagogical Sciences, Professor, Kharkiv National Technical University of Agriculture Named After Petro Vasylenko, Kharkiv, Ukraine

ORCIDID: 0000-0002-3130-6112

e-mail:nagaevviktor1966@gmail.com

Litvinchuk Svitlana, Candidate of Pedagogical Sciences, Associate Professor of the Department of Professional Training Methodology, Mykolayiv National Agrarian University, Mykolaiv, Ukraine

ORCID ID:0000-0002-9885-7234

e-mail:svitlanalitvinchk@ukr.net

Taikhrib Katerina, Assistant Professor of the Department of Professional Training Methodology, Mykolayiv National Agrarian University, Mykolaiv, Ukraine

ORCID ID:0000-0002-3394-2024

e-mail:katri_87@ukr.net

Yablunovska Katerina, Assistant Professor of the Department of Professional Training Methodology, Mykolayiv National Agrarian University, Mykolaiv, Ukraine

ORCID ID:0000-0002-5215-1594

e-mail:yablunovskayakaterina@ukr.net

\title{
Modular-Competence Aspect of the Teaching Process Future Economists in Accordance with the Requirements of the Bolonga Process
}

\begin{abstract}
Introduction. This article researches the didactic principles of the modular-competence approach for teaching future economists in higher education through innovative pedagogical activities. The actual issues of the innovative pedagogical activity, the competence approach for future economists learning and the specific features of modular learning are analyzed. The didactic conditions of the modular-competence approach for teaching students, which determines the quality assurance of the professional training of future specialists in higher education, are highlighted.

Purpose. The purpose of this article is to study the didactic principles of forming a modular-competence approach to the training of future economists in higher education through of the Bolonga process.

Results. Practical research was carried out, on the basis of which the technology of acquiring competencies by future economists while studying the modules of the discipline "Management psychology" was developed. The percentage of competencies was calculated, which is prescribed to acquire each of the two modules in the process of working with lectures, for the work with practical tasks and for the execution of individual tasks.

Conclusions. It has been proved that the preparation effectiveness of future economists in the context of the Bologna Process will be significantly improved, and the formation of professional competencies of those who get higher education, provides an opportunity to successfully engage in professional activities in the sphere of future economists after graduation from higher education institutions.

Keywords: innovative pedagogical activity; future economists; modular training; modular-competence approach; competence-oriented training, professional competence.
\end{abstract}

\section{УДК 378.09:378.147}

Нагаєв В. М., доктор педагогічних наук, професор, Харківський національний технічний університет сільського господарства імені Петра Василенка, Харків, Україна

Літвінчук С. Б., кандидат педагогічних наук, доцент, Миколаївський національний аграрний університет, Миколаїв, Україна

Тайхриб К. А., асистент, Миколаївський національний аграрний університет, Миколаїв, Україна

яблуновськ К. О., асистент, Миколаївський національний аграрний університет, Миколаїв, Україна

\section{Модульно-компетентнісні аспекти процесу навчання майбутніх економістів відповідно до вимог} Болонського процесу

Анотація. у статті проаналізовано актуальні питання інноваційної педагогічної діяльності, компетентнісного підходу до навчання студентів та специфічні особливості модульного навчання. Виділено дидактичні умови модульно-компетентнісного підходу до навчання майбутніх економістів, обумовлюючі забезпечення якості професійної підготовки майбутніх спеціалістів у вищій школі.

Стаття надійшла до редакції: 09.09.2020

Received: 09 September 2020 
Метою статті є дослідження дидактичних засад модульно-компетентнісного підходу до навчання майбутніх економістів у вищій школі в контексті інноваційної педагогічної діяльності.

Проведено аналіз праць науковців з питань модульного навчання та проаналізовано означене навчання у напрямі спрямованості кожного модуля з урахуванням компетентностей за фахом розкриття і засвоєння наскрізних принципів майбутньої професійної діяльності економіста. Звернено увагу на структуру компетентнісної освітньої парадигми, яка містить окремі напрями, покладені в основу розробки модульно-компетентнісної технології підготовки майбутніх фахівців. Окреслено основні напрями модернізації підготовки здобувачів вищої освіти економічних спеціальностей відповідно до компетентнісної парадигми, що слугують підгрунтям для побудови змісту компетентнісно зорієнтованого навчання на модульній основі. Виокремлено загальні та фахові компетентності. На прикладі вивчення дисципліни «Психологія управління» технологічно представлено, як формуються компетентності у майбутнього економіста відповідно до модулів на основі вимог Болонського процесу. Проведено практичне дослідження, на основі якого була розроблена технологія набуття компетентностей майбутніми економістами при вивченні модулів дисципліни «Психологія управління». Підраховано відсоток набуття компетентностей, що передбачає кожен із двох модулів у процесі опрацювання лекцій, роботи з практичними завданнями та за виконання самостійних робіт.

Доведено, що ефективність підготовки майбутніх спеціалістів у контексті Болонського процесу буде значно покращена, а формування у здобувачів вищої освіти професійних компетенцій сформують можливість після закінчення закладу вищої освіти успішно займатися професійною діяльністю в галузі економіки.

Ключові слова: інноваційна педагогічна діяльність; майбутні економісти; модульне навчання; модульнокомпетентнісний підхід; компетентнісно орієнтоване навчання; професійна компетентність.

Formulation of the problem. The socioeconomic transformations taking place in Ukraine have caused the need to upgrade the educational system in higher education institutions. In order to provide a new level of quality training for future economists, who can flexibly rebuild the direction and content of their production in connection with changes in the requirements of the labour market; it is necessary to apply non-traditional approaches to the education and training of young people.

Undoubtedly, higher, vocational education should be aimed at the development of natural abilities for active, creative thinking and the formation of innovative, transformative intelligence, which is realized through professional practice. In the process of learning, a welldeveloped, independent, self-sufficient person, who would be guided by his own beliefs and self-conscious analysis, should be formed. It is necessary to move from formal teaching aimed at gaining knowledge to learning which leads to the mastery of competencies. Applicants of higher education are obligated to take responsibility for mastering the knowledge, skills, and the acquisition of the necessary competences. In view of this, the goal of this training future economists is the personal and professional development of future specialists. These goals can be realized in the process of solving educational tasks, such as the formation of social-professional orientation, social-professional competence, professional qualities, and the professional-significant psychological properties of future specialists.

Modern science has a significant positive experience in the field of professional pedagogy. However, educational potential has not been fully realized, which has prompted new scientific research to improve the quality of the training of future economists in higher education through the Bologna Declaration.

Analysis of recent research and publications. It is important to note that the problem with the development of professional competences of high school students is being studied by many scholars. A detailed analysis of the regularities of the formation of professional competences has been examined in scientific works by V. Andrushchenko, G. Vasyanovich, B. Gershunsky, I. Zyazun, V. Kozakov; the theory of vocational education S. Batishev, R. Gurevich, A. Dyomin, O. Dubinchuk, P. Luzan, V. Madzigon, V. Manko, M Makhmutov, N. Nichkalo, V. Sidorenko; the theory of modular studies in high school — A. Aleksuk, A. Andrushchuk, I. Bogdanova, T. Vasil'eva, V. Okon, J. Russell, P. Sikorsky, E. Skovin, A. Furman, P. Yutsavichene; the psychological foundations of vocational education $-\mathrm{G}$. Bal, O. Leontiev, L. Vygotskyi, O. Kulchytska, V. Semichenko, N. Talizina.

The scientific and pedagogical literature presents the main aspects of the competence approaches, which were studied by such scholars as I. Bekh, V. Bykov, S. Vitvitska, R. Gurevich, A. Dubaseniuk, M. Kademiya, I. Kozinets, M. Kozyar, O. Lokshina, N. Nichkalo, V. Petruk, N. Pobirchenko, O. Pometun, J. Raven, G. Tarasenko, Y. Trigub, Y. Frolov, A. Khutorsky, V. Shakhov, V. Yagupov and others.

At the same time, problems with the formation of professional competences of future economists in the manufacturing industries in the modern economy through modular studies in higher education in the process of innovative pedagogical activity, which will influence the implementation of the basic principles of the Bologna agreements, remain insufficiently researched.

Therefore, the purpose of this article is to study the didactic principles of forming a modular-competence approach to the training of future economists in higher education through of the Bolonga process. In regards to the problem formulated, O. Kobernyk points out that competence in a certain field is a combination of relevant knowledge, experience and abilities that allow us to reasonably analyze, predict and effectively act in the field of future activity [8].

Outline of the main research material. The traditional paradigm of higher education, in which the emphasis is on the cognitive aspect of vocational education, is no longer promising today. The fundamental changes taking place in 
the life of society require modernization of approaches for the vocational education of future specialists.

As the academic I. Ziyuzun noted, the traditional model of education, aims at transferring the necessary knowledge, skills and abilities to the future specialist, is losing its promise. There is a need to change the strategic, global goals of education, rearranging the emphasis to the specialist's knowledge of their human and personal qualities, which appear both as a goal and as a means of preparing them for future professional activities [6].

Therefore, a need for the transition of the "knowledgeable" paradigm of vocational education has appeared, which determines the instrumental role of the teacher, to innovative vocational education, which pursues the goals of forming creative individuality of a specialist capable of developing, mastering and using innovative projects.

In order to realize the specified tasks of innovative pedagogical activity in high schools, modern pedagogy provides the competence educational paradigm. The structure of the competence approach contains the following indicative basis:

1) The competent performance of activities based on the image of the intended product and the logic of its creation;

2) Conceptual knowledge about the essence of the process and the result of the activity;

3) Systems tested in their own experience of ways of activity (thinking, organizational, communicative, informational, etc.);

4) The performance of this activity in problematic conditions (in case of incompleteness of the task conditions, lack of information and time, uncertainty of causal relationships;

5) Reflection and self-control of their actions [13].

In the aspect of our problems, researchers point out that the higher component of the individual is professional competence, which is understood as an integral characteristic of business and personal qualities of specialists, which reflects the level of knowledge, skills and abilities, experience, abilities sufficient for the professional activity. According to the researchers, professional competence is the mobility of knowledge, the flexibility of the method, the criticality of thinking, the systematic style of thinking, information literacy, etc. The criterion for their formation is the productivity of the specialist's work and his high authority in the field of professional activity.

It is worthwhile to draw attention to the fact that the new educational strategy of the country's higher educational institutions, which clearly defines the focus on qualitative learning outcomes and the use of active teaching methods, is directly linked to a competenceoriented approach, and is aimed at implementing the basic principles of the Bologna Declaration. Under these conditions, the modular construction of training courses becomes of particular importance.
Modular learning was born in the 1960s in US universities and research institutes. The founder of such training is S. Postlethwaite, who first put forward the "Concept of units in the content of education," according to which a small amount of educational material can be considered a separate topic and included in the program of classes [19]. These units were named by S. Postlethwaite "mini-courses". They have become widespread in US colleges, where, according to J. Russell [20], many of their varieties arose, such as the package, the training package, the package of individual learning, and so on. By definition, D. Russell's module is a training package that covers one conceptual "unit" of learning material [20].

The theoretical foundation of modular studies in native science was laid by A. Alexyuk, who considered such a system of education as an integral system of educational process, integrating into itself a sufficient structure of didactic means necessary for solving the main objectives of education, provides students with modern higher education [2].

Based on research by scholars, it can be argued that the main feature of modular learning is the independent search for knowledge by students, the formation of skills and abilities. Czech teacher Y. Komensky emphasized on this issue: "By alpha and omega of our didactics, let there be a study and discovery of a method in which less would be taught by teachers, and students would learn more" $[9, p$. 14].

According to P. Yutsiavichen [18], the theory of modular learning is based on specific principles closely related to the general-didactic, which is the guiding principle, the basic rule of conduct and behavior in accordance with the laws determined by science. The general orientation of modular learning, its purpose, content and technology of organization determine the principles of modularity, dynamism, efficiency and efficiency of knowledge and their system, flexibility, conscious outlook, versatile methodological counseling and parity.

The essence of modular training, according to P. Yutsiavichen, lies in the fact that the student can independently or completely independently work with his proposed individual curriculum, which consists of a target program of action, a bank of information and methodological guidance to achieve the set didactic goal. A module is a target functional node, which combines the training content and the technology of mastering it [18].

It is appropriate to draw attention to the fact that in today's conditions of entry into the European educational space there is an urgent need for the existence of open and flexible educational and training structures that will make it possible to adapt to constantly changing conditions of production, science, and to adapt to local conditions. It is these requirements that correspond to the modular approach that allows flexible design of the content of training from logically completed blocks, to integrate various forms and training methods, to choose 
the most effective ones for different audiences of students who can independently process the training material at a convenient pace for them.

In the high school, the tasks of not only theoretical substantiation and methodological support of the educational process, but also the development of such a modular construction of a learning process that meets the requirements for the training of highly skilled personnel, must be addressed. Therefore, in the context of innovative pedagogical activity, it is expedient to consider a modular-competence approach for the training of students of higher education, which provides as a learning goal a set of professional competencies of students, and as means of its achievement - a modular construction of the content and structure of vocational training. And this means that the principle in assessing the effectiveness of education is not the planning and implementation of the educational process, but its results - the knowledge, competences and skills acquired by students.

It is important to note that during the design of the training modules, one must justify the place of each module and its role in shaping the competency profile as a result of the learning process. The above structure and purposeful sequence of the study of modules contribute to the development and deepening of the professional competences laid down in the process of studying the theoretical foundations of the sciences throughout the process of studying at a higher school.

In order to provide a competent approach to the process of studying at a higher school, it is necessary to simulate the production problem or situation in each module and determine their practical application in future professional activities. Such tasks should focus future economists of higher educational institutions on the study of the essence of production processes, and not on the learning process at all. Their solution requires the independent creative efforts of future economists, which will determine the competent approach for the professional training of future economists in requirements of the Bolonga process.

Our research shows that the modular-competence approach for teaching future economists in higher education has significant didactic capabilities and allows us to solve the following pedagogical tasks:

- Construction and operational implementation of prognostic models of the content of educational and cognitive activity;

- The formation of new content structures to ensure the effective organization of the educational process;

- Ensuring the unity of the theoretical and applied aspects of the process of studying at a higher school;

- Increasing the informality, systemic and functional content of the discipline through the allocation of invariant knowledge, effective theoretical generalization, generalization of the categorical synthesis of concepts, the use of symbolic and graphic forms of manifestation;
- Facilitating the rapid implementation of new methodological ideas and advanced pedagogical experience;

- Improving the methodological provision of the learning process.

Modular training in the modernization of higher education should be built taking into account the current level of development of production. In these conditions, the socialization of the individual will be no less important a task of the high school than the training of highly skilled specialists. On the basis of our study, we outline the following conditions for the effectiveness of the modularcompetence approach to the process of studying future economists in higher education through innovative pedagogical activities:

- The formation of future economists understanding of the need for the development of modern production and the attitude towards it as his own scientific and professional activity;

- The formation of motivation in the process of learning as a desire for cooperation and joint creative activity through production situations and involvement of future economists in practical activities;

- The realization of person-oriented training with the organization of active independent work in modules, when the student himself organizes the process of studying, which allows him to master the educational material more deeply and consciously;

- Filling the contents of the modules in terms of their features and complexity of application in the manufacturing sector, as well as planning for the results of training in professional competences;

- The development of future economists cognitive independence through the use of various problemdeveloping methods and forms of training (practical work of a research nature, solving of problematic production situations, visiting seminars and practical classes for production, etc.);

- Simulations of future professional activity organized within the modules to replicate real life situations

- The development of the spiritual culture of the individual, as the success in future economists activities depends to a large extent on the formation of general cultural competences and on the spiritual and moral potential of the future specialist.

In the process of designing training modules in the context of the preparation of future economists, it is necessary to ground the place for each module and its role in shaping the competency profile as a result of the learning process. The above structure and the deliberate sequence of studying the modules contribute to the development and deepening of the professional competences laid down in the process of studying the theoretical foundations of science throughout the entire process of studying at a higher school.

In order to implement module-competent technology for the preparation of future economists, it is necessary to simulate the problem or situation in each module and 
determine their practical application in future professional activities. Such tasks should focus on higher education graduates of future economists on the study of the essence of production processes in the relevant field, and not on the learning process at all. Their solution requires independent creative efforts of future economists, which are the basis of the use of modularcompetent technology in accordance with the requirements of the Bologna Process.

The distribution of competences in disciplines is carried out in accordance with the curriculum approved by the issuing department and the Academic Council of the University. All of these competencies are formed from the disciplines in the curriculum. Let's consider in more detail the technology of forming competencies in the economic industry in the example of studying one discipline in the context of a modular approach in accordance with the requirements of the Bologna Process.

For example, the discipline "Management psychology" forms the following competencies: GC1, GC3, GC4, GC5, PC1, PC2, PC5, PC 12, PC15, which is $45 \%$ of the total number.
Here is a formula for calculating the percentage of general (1) and professional (2) competencies in the study course of disciplines:

$$
\begin{gathered}
\varepsilon_{G C}=\frac{D_{G C_{1}}+D_{G C_{2}}+D_{G C_{3}}+\cdots+D_{G C_{n}}}{n} \cdot 100 \% \\
\varepsilon_{P C}=\frac{D_{P C_{1}}+D_{P C_{2}}+D_{P C_{3}}+\cdots+D_{P C_{m}}}{m} \cdot 100 \%
\end{gathered}
$$

where DGC - disciplines stipulated by the curriculum for the specialty "Economy", forming the corresponding general competencies;

DPC - discipline that the curriculum for the specialty

"Economy" which form the appropriate professional competence;

$n, m$ - the number of disciplines envisaging the acquisition of general and professional competencies, respectively.

Based on the results of these calculations, we present in Figure 1 an example of a scheme that reflects the percentage of competencies in each module when studying the discipline "Management psychology".

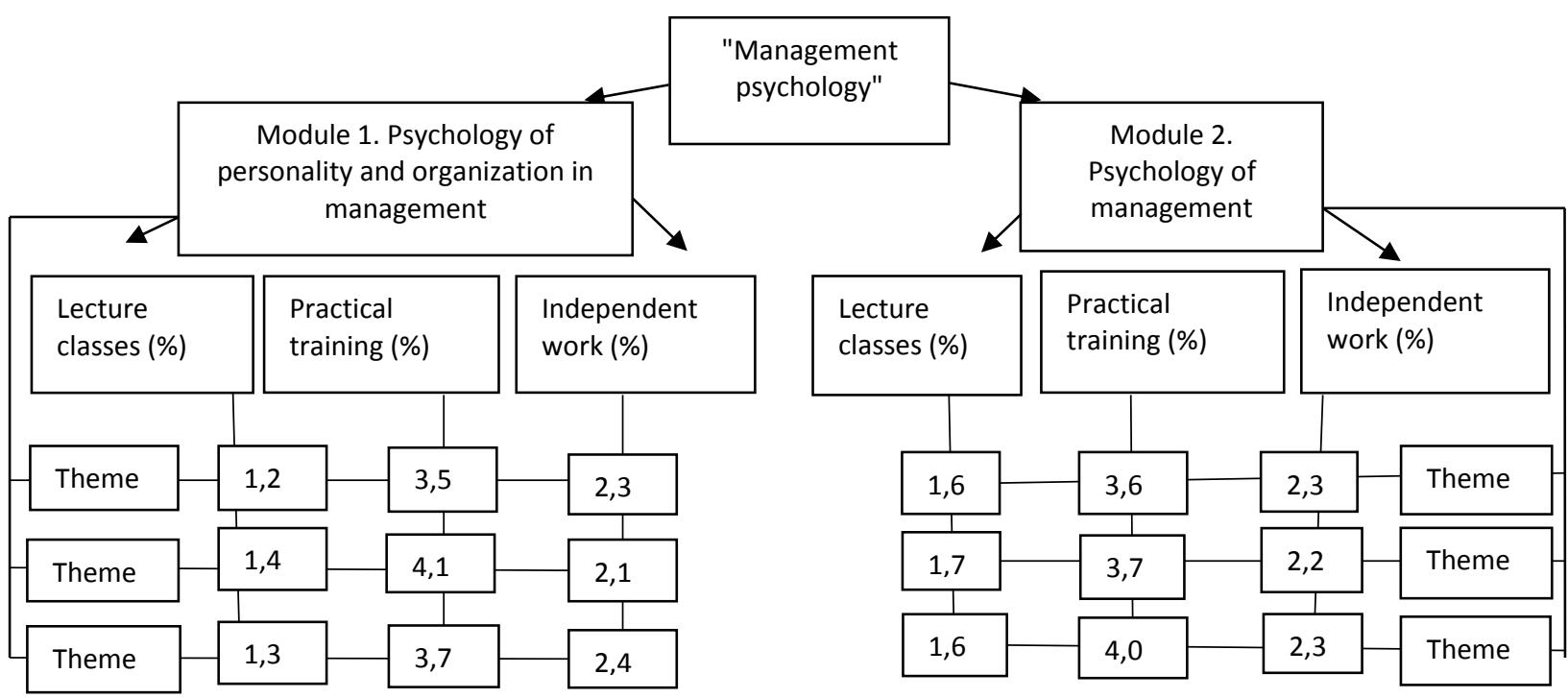

Figure 1 -The technology of acquiring competencies for the future economists in the study of modules of the discipline "Management psychology"

Source: developed by the authors

According to the above-mentioned scheme, each module consists of lectures, practical classes and independent work. When studying topics in module 1, $22 \%$ of the competencies are formed from the total, while in the module 2 - 23\%. Each module involves studying three topics. In the first module "Psychology of personality and organization in management" in the study of discipline is envisaged for all types of work on the topic 1 "Theoretical foundations of management psychology" gaining $7 \%$ of competencies, of which, for the development of lectures $1,2 \%$, for work practical tasks -
$3,5 \%$, performance of independent work involves gaining $2,3 \%$ of competencies.

Theme 2 "Psychology of personality and activity of the head" provides for the acquisition of $7,6 \%$ of competencies, of which for the processing of lectures $1,4 \%$, for working with practical tasks $-4,1 \%$, execution independent work involves gaining $2.1 \%$ of competencies. From topic 3, "Psychology of organization in management", it is anticipated that $7.4 \%$ of competencies will be acquired, of which $1.3 \%$ will be used for lectures, $3.7 \%$ for practical assignments, and the implementation of 
independent work will require the acquisition of $2.4 \%$ of competencies.

The second module, "Psychology of management", involves gaining $23 \%$ of the competencies. From topic 1 , "Psychology of managerial decisions", it is anticipated to acquire $7.5 \%$ of the competencies, of which, for the processing of lectures $1.6 \%$, for work with practical tasks $3.6 \%$, the implementation of independent work involves gaining 2.3\% competencies. From theme 2, "Psychological features of motivational functions in management", it is expected to acquire $7,6 \%$ of the competencies, of which $1,7 \%$ for lectures, $3,7 \%$ for practical tasks, $3,7 \%$ for practical tasks, and $2,2 \%$ of competencies will be achieved. From topic 3 "Psychological features of the control function in management", it is expected that $7,9 \%$ of competencies will be acquired, of which $1,6 \%$ will be used for the preparation of lectures, $4 \%$ for practical tasks, and the implementation of independent work involves acquiring $2,3 \%$ of competencies.

Taking into account the aforementioned, it can be argued that the module construction of the training of future economists in higher education institutions will promote the implementation of a competent approach in determining the requirements for their level of professional training. At the same time, scholars argue that the essential components of the module are its logical completeness, autonomy and complexity.

To determine the optimum technology of future economists training, a survey was conducted among 38 applicants of the higher education specialty "Economy" in the Faculty of Management at Mykolayiv National Agrarian University.

Of the total number of respondents, $76 \%$ believe that it is necessary to formulate, in the process of preparation, the peculiarities of the technological development of modern production and the attitude towards it as their proper scientific and professional activity.

The respondents defined the degree of influence on the quality of the training of higher education graduates in the future economists as follows: $6 \%$ of the respondents considered it necessary to fill the content of the modules with the programmed educational material with traditional tasks, $14 \%$ believe that content of the modules should be supplemented with a set of production tasks, $70 \%$ are confident in the use of training modules with production tasks based on acquiring competencies in the specialty associated with the modern production process.

It should be noted that $89 \%$ say that they would be motivated in the learning process by resolving industrial situations and engaging in practical activities, taking into account the acquisition of professional competencies.

The role of the teacher within the framework of the application of modular-competent technology for future economists was determined as follows: $43 \%$ consider it is necessary to organize the process of study within the module; $46 \%$ are of the opinion that the teacher should direct the work of the future economists and manage it; only $11 \%$ believe that the teacher should be guided by the traditional method of teaching.

The survey provides an opportunity to argue that individual forms and teaching methods will contribute to the development of cognitive autonomy of future economists. Responses were distributed as follows: $66 \%$ believe that the solution of problematic production situations and outgoing laboratory and practical classes at work are capable of acquiring professional competencies within the framework of modular training. According to $14 \%$ of higher education students, traditional lectures and practical classes are capable of forming professional competencies. According to $20 \%$ of the respondents, business games using practical tasks are an integral part of the acquisition of professional competencies within the framework of module training.

Thinking about our problems we can assume that the effectiveness of innovative pedagogical activity through the Bologna process leads to a modular construction of training sessions and the formation of students with professional competencies, which make it possible to successfully engage in professional activities immediately after graduation.

Conclusions. The studies conducted by us allow us to conclude on the significance of the modular-competence approach to learning in the context of innovative pedagogical activities in higher education, which promotes:

- The stimulation of innovative pedagogical activity in higher education institutions;

- The formation of professional thinking and future economists ability to study independently;

- Taking into account individual personal qualities of future economists;

- Training of professionally competent, competitive and mobile specialists who are able to quickly adapt to a dynamic socio-technological and professional-production environment;

- Stimulating the quality of learning programs with the use of modern diagnostic methods.

We believe that the implementation of the abovementioned approaches will significantly increase the professional competence of future specialists, and hence the quality of education at higher education, which in turn will contribute to the implementation of the basic principles of the Bologna Declaration.

Our further research is to develop materials for the formation of professional competences of future economists in the design and creative activities of future economists of higher education. A successful solution to this problem will contribute to improving the quality of future economists training through the Bologna Process, as well as the formation of competitive, high-level creative opportunities for the development of Ukraine's economic potential. 
Електронне наукове фахове видання з економічних наук “Modern Economics», №23 (2020), 136-142 https://modecon.mnau.edu.ua | ISSN 2521-6392

\section{References:}

1. Aleksieiev, Yu. (1998). Ukraina: osvita i derzhava (1987-1997). K. : Ekspres-ob'iava [in Ukrainian].

2. Aleksiuk, A. M. (1993). Pedahohika vyschoi shkoly. Kurs lektsij : Modul'ne navchannia. Kyiv [in Ukrainian].

3. Bohdanova, I. M. (2003). Profesijno-pedahohichna pidhotovka majbutnikh vykladachiv na osnovi innovatsijnykh tekhnolohij: Dys. d-ra ped. n... 13.00.04. Kyiv [in Ukrainian].

4. Vysshee obrazovanie v HHI veke (1998). Vsemirnyj statisticheskij obzor po vysshemu obrazovaniju 1980-1995 g.g. JuNESKO: Parizh [in Russ.].

5. Zhuravskyj, V. S., Zghurovs'kyj, M. Z. (2003). Bolons'kyj protses: holovni pryntsypy vkhodzhennia v ievropejs'kyj prostir vyschoi osvity. K. : Politekhnika NUTU „KPI” [in Ukrainian].

6. Ziaziun, I. A. (2004). Neperervna osvita : Kontseptual'ni zasady i suchasni tekhnolohii. Tvorcha osobystist' u systemi neperervnoi osvity Kharkiv : KhDPU, 8-16 [in Ukrainian].

7. Zazvjaginskij, V. I. (1982). Metodologija i metodika didakticheskogo issledovanija. M. : Pedagogika [in Russ.].

8. Kobernyk, O. M. (2008). Formuvannia tekhnolohichnoi kompetentnosti uchniv u protsesi trudovoho navchannia. Naukovyj chasopys Natsional'noho pedahohichnoho universytetu imeni M. P. Drahomanova. Seriia 5. Pedahohichni nauky: realii ta perspektyvy. Vypusk 13. Zb. nauk. prats' / Zared. prof. M. S. Kortsia, prof. P.V. Dmytrenka. K. : Vyd.-vo NPU imeni M. P. Drahomanova, $110-113$ [in Ukrainian].

9. Komenskij, Ja. A. (1940). Didakticheskie principy. M. : Uchpedgiz [in Russ.].

10. Klarin, M. V. (1998). Innovacii v mirovoj pedagogike : obuchenie na osnove issledovanija, igry i diskussii. (Analiz zarubezhnogo opyta). Riga : NPI „Jeksperiment” [in Russ.].

11. Kozlovs'ka, I. M. \& Kmit, Ya. M. (2001). Dydaktychne doslidzhennia na eksperymental'nomu majdanchyku : Metodolohichni rekomendatsii. L'viv, $68 \mathrm{~s}$. [in Ukrainian].

12. Majboroda, V. K. (1992). Vyscha pedahohichna osvita v Ukraini : istoriia, dosvid, uroky (1917 - 1985r.r.) / Za red. Luhovoho V. I. K. : Lybid' [in Ukrainian].

13. Mitjaeva, A. M. (2008). Soderzhanie mnogourovnevogo vysshego obrazovanija v uslovijah realizacii kompetentnostnoj modeli. Pedagogika, 8 [in Russ.].

14. Nychkalo, N. H. (1994). Metodolohichni problemy bezperervnoi profesijnoi osvity. Psykholoho-pedahohichni problemy profesijnoi osvity [in Ukrainian].

15. Pedahohichni tekhnolohii u neperervnij osviti (2001). (Sysoieva S. O., Aleksiuk M. A., Volovyk P. M., Kul'chyts'ka O. I. ta in.) za red. S. O. Sysoievoi. K. : Vipol [in Ukrainian].

16. Ziaziun, I. A. (2000.). Neperervna profesijna osvita : problemy, poshuky, perspektyvy. K. : Vyd. „Vypol” [in Ukrainian].

17. Sysoieva, S. (2000). Osvitni tekhnolohii : metodychnyj aspect. Profesijna osvita : pedahohika i tekhnolohiia. Kyiv: Chenstokhova [in Ukrainian].

18. Jucjavichene, P. A. (1989). Teorija i praktika modul'nogo obuchenija. Kaunas : Shiesa [in Russ.]

19. Postlethwait, S. N. (1969). Time for Microcoursees? The Library College Journal, 2(2) [in English].

20. Russel, J. D. (1974). Modular Instruction. A. Guide to the Desing, Selection Utilization and Evaluation of modular Materials. Minneapolis, Minnesota: Burgess Publishing Company [in English].

Ця робота ліцензована Creative Commons Attribution 4.0 International License 